\title{
Histopathological analysis of the reproductive system of male dogs experimentally infected with Toxoplasma gondii
}

\author{
Análise histopatológica do sistema reprodutor de cães machos experimentalmente infectados com \\ Toxoplasma gondii
}

\author{
Tiago Pereira Arantes ${ }^{\mathrm{I}}$ Welber Daniel Zanetti Lopes $^{\mathrm{I}^{*}}$ Roberta Machado Ferreira $^{\mathrm{I}}$ \\ Juliana de Souza Pinto Pieroni ${ }^{\mathrm{I}}$ Vanessa Marigo Rocha Pinto ${ }^{\mathrm{I}}$ Thaís Rabelo dos Santos ${ }^{\mathrm{I}}$ \\ Claúdio Alessandro Sakamoto ${ }^{\mathrm{I}}$ Alvimar José da Costa ${ }^{\mathrm{I}}$
}

\begin{abstract}
The present research aimed to describe possible histopathological alterations in the reproductive system (testicles and epididymis) of male dogs experimentally infected with Toxoplasma gondii. Canines $(n=10)$ serologically negative for T. gondii were selected and distributed into three experimental groups: GI, 3 inoculated with $2.0 \times 10^{5} \mathrm{P}$ strain oocysts; GII, 3 infected with $1.0 \times 10^{6} \mathrm{RH}$ strain tachyzoites; and GIII, 4 control dogs. Antibody research (IFAT) against $\mathbf{T}$. gondii was realized. Toxoplasma gondii infection was confirmed by seroconversion of the 6 males infected with tachyzoites and oocysts from postinoculation day (PID) 7 and 14, respectively. At PID 70, all dogs were submitted to orchiectomy and testicle and epididymis samples were collected and histologically processed for examination under optical microscope. The following alterations were diagnosed: mild and moderate mononuclear inflammatory infiltrate in the epididymis, moderate cellular edema, hydropic degeneration and moderate interstitial fibrosis in seminiferous tubules. The histopathological results in the present research, isolation of $\mathbf{T}$. gondii in testicle and epididymis fragments by immunohistochemistry and results from the literature by other authors in different tissues, all infer that the alterations observed in dogs infected with T. gondii are suggestive of toxoplasmic infection.
\end{abstract}

Key words: canine, experimental infection, toxoplasmosis, histopathology, testicle, epididymis.

\section{RESUMO}

O presente trabalho teve como objetivo descrever eventuais alterações histopatológicas no sistema reprodutor (testículo e epidídimo) de cães machos experimentalmente infectados com Toxoplasma gondii. Para tal, 10 animais sorologicamente negativos para T. gondii foram selecionados

\begin{abstract}
e distribuídos em três grupos experimentais: GI - três cães inoculados com 2,0 × $10^{5}$ oocistos da cepa P, GII - três cães infectados com 1,0 × $10^{6}$ taquizoítos da cepa $\mathrm{RH}$ e GIII quatro cães mantidos como controle. Pesquisa de anticorpos (IFI) contra T. gondii foi realizada. A infecção por T. gondii confirmou-se pela soroconversão de todos os machos infectados a partir do 7o e do 14ํㅓㅁ dia pós-inoculação (DPI) para cães que receberam taquizoítos e oocistos respectivamente. Decorridos 70DPI, realizou-se, em todos os cães, orquiectomia, e amostras (testículo e epidídimo) foram coletadas e processadas histologicamente para leitura em microscópio óptico. As seguintes alterações foram diagnosticadas: infiltrado inflamatório mononuclear leve e moderado em epidídimo, edema celular moderado, degeneração hidrópica e fibrose intersticial moderada em túbulos seminíferos. Os resultados histopatológicos do presente trabalho, aliados ao isolamento do T. gondii em fragmentos de testículo e epidídimo pela imunoistoquímica, juntamente com os resultados encontrados na literatura por outros autores em diferentes tecidos, permitem inferir que as alterações encontradas nos cães infectados com o respectivo protozoário são sugestivas de infecção toxoplásmica.
\end{abstract}

Palavras-chave: canina, infecção experimental, toxoplasmose, histopatologia, testículo, epidídimo.

\section{INTRODUCTION}

Toxoplasmosis, caused by etiological agent Toxoplasma gondii (NICOLLE \& MANCEAUX, 1909), is a protozoonosis of expressive importance that can provoke serious harm in both humans and animals (DUBEY et al., 1995). In dogs, this infirmity was first

ICentro de Pesquisas em Sanidade Animal (CPPAR), Faculdade de Ciências Agrárias e Veterinárias (FCAV), Universidade Estadual Paulista (UNESP). Via de acesso Prof. Paulo Donatto Castellane, s/n, 14884-900, Jaboticabal, SP, Brasil. E-mail: wdzlopes@hotmail.com.*Autor para correspondência. 
described by MELLO (1910). Since then, toxoplasmosis has been reported in dogs in several countries (SILVA et al., 2002); however, literature regarding clinical and histopathological alterations in canines affected by this zoonosis remains scarce (BRITO et al., 2002).

Researches involving experimental infection (controlled and approximating natural conditions) are the most indicated for providing clinical, laboratorial and epidemiological data concerning the infirmity, especially in relation to prophylaxis.

Ocular lesions were the principal abnormalities highlighted in a study of experimental canine toxoplasmosis by FIALHO (1953). HEDLEY (1963) verified that experimental toxoplasmic infection in bitches provoked death in the puppies from postnatal day 4 to 75 , independent of the gestational stage at infection. BRESCIANI (2003) verified that bitches carrying toxoplasmic infection are susceptible to $\boldsymbol{T}$. gondii inoculation and that severe alterations can be observed in both primary infected bitches and those reinfected by the coccid.

To the best of our knowledge, although the isolation of T. gondii in dog semen samples has been realized successfully (ARANTES, 2005), references regarding to the histopathological analyses of the reproductive system of male dogs carrying toxoplasmic infection are inexistent in the literature. The objective of the present work was to verify possible histological alterations in the reproductive system, testicles and epididymis, of male dogs experimentally infected with Toxoplasma gondii.

\section{MATERIAL AND METHODS}

Strains 'P' (JAMARA \& VIEIRA, 1991) and 'RH' (SABIN, 1941) were used from stocks maintained at the Animal Health Research Center (Centro de Pesquisas em Sanidade Animal, CPPAR) of the Faculdade de Ciências Agrárias e Veterinárias, FCAVUNESP. The inoculateswere obtained by periodic inoculations of brain cysts (' $P$ ' strain) and/or tachyzoites ('RH' strain), diluted in saline buffer, in albino mice. Toxoplasma gondii oocysts were obtained using a technique similar to that described by DUBEY et al. (1972). The animals were maintained in individual bays belonging to CPPAR, with water and feed provided ad libitum.

Ten male dogs presenting good clinical and reproductive conditions and serologically negative for T. gondii, were randomly selected, identified and inoculated with the respective protozoan: GI, 3 dogs inoculated with $2.0 \times 10^{5} \mathrm{P}$ strain oocysts/animal, via oral; GII, 3 dogs infected with $1.0 \times 10^{6} \mathrm{RH}$ strain tachyzoites/animal, via subcutaneous; and GIII, 4 dogs maintained as controls.

Serological exams to detect antibodies against other infectious diseases that could provoke reproductive disorders (brucellosis, neosporosis and leptospirosis) were realized on all experimental canines, pre and post inoculation.

The presence of IgG class antibodies against $\mathbf{T}$. gondii was investigated by indirect immunofluorescence, considering 1:16 dilution as the cut-off, (IFAT; CAMARGO, 1964) in serum obtained from all the dogs two days prior to inoculation, on post inoculation day (PID) 7 and weekly up to PID 70. On PID 70, all the canines, control group and inoculated, were orchiectomized and testicle and epididymis samples were collected and fixed in $10 \%$ formalin for 48-72h. The material was processed by histopathological technique and embedded in paraffin. Five $\mu \mathrm{m}$ semi-serially sections were placed on slides and stained with hematoxylin and eosin (HE) for examination under optical microscope. The immunohistochemical exams were realized by immunoenzymatic method of amplification, with avidin-biotinperoxidase (Kit LSAB/HRP, Dako, USA) as GUESDON et al. (1979), using of polyclonal antibody against $\boldsymbol{T}$. gondii produced by MINEO (2002 - personal communication). The dilution optimized for the immunohistochemical test was 1:5000.

\section{RESULTS AND DISCUSSION}

Experimental infection with T. gondii in the reproductive dogs was confirmed by the seroconversion of all the inoculated males. In dogs presenting acute infection, no relevant clinical signs that could be attributed to T. gondii were observed; i.e., the state of toxoplasmosis was asymptomatic. It should be noted that the control group showed no alterations, clinical or immunogenic, throughout the entire experimental period.

The titer values for antibodies against $\boldsymbol{T}$. gondii revealed high IgG antibody levels on PID 14 and 21 (IFAT=4,096), in dogs inoculated with RH strain tachyzoites. In dogs inoculated with P strain oocysts, titer elevation was slower, achieving maximum serological values of $1: 1,024$ on PIDs 28 .

Using immunohistochemistry, it was possible to detect the respective T. gondii protozoan in testicle and epididymis fragments in all canines infected experimentally (Figure 1).

The presence of T. gondii was not verified in the tissues sections analyzed by histopathological exams; however, lesions were observed in the material 


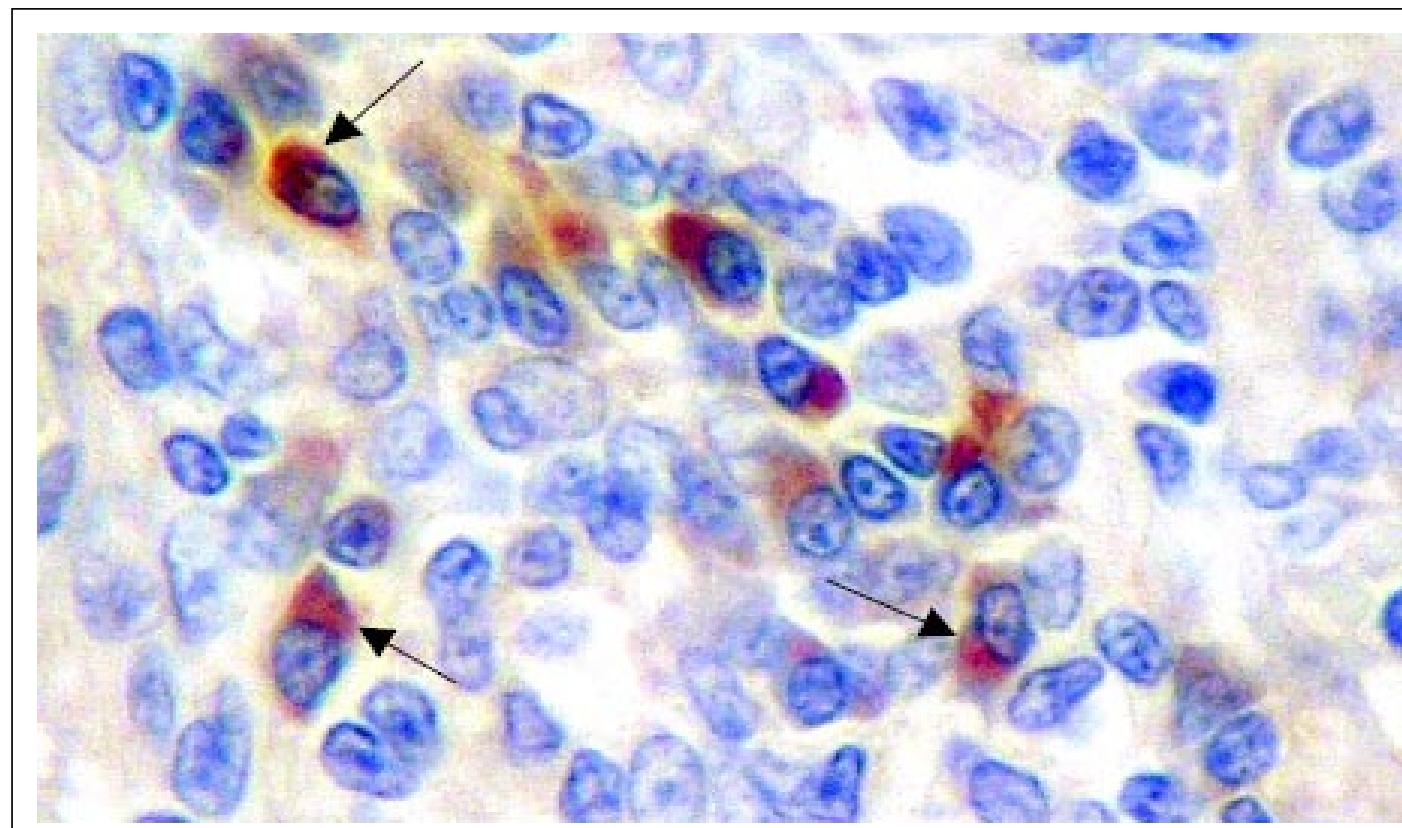

Figure 1 - Toxoplasma gondii immunoreactivity in canine epididymis inoculated with $1 \times 10^{6}$ Toxoplasma gondii tachyzoites. Objective lens $40 x$.

collected from dogs inoculated with oocysts or tachyzoites, but not in dogs from the control group (Table 1), suggesting that the alterations observed were result of toxoplasmic infection. This may have been due to a combination of low density of parasites within the tissue and the inevitable sampling error.

The histopathological results of exams revealed the following abnormalities: mild and moderate mononuclear inflammatory infiltrate, moderate interstitial fibrosis in the epididymis and moderate cellular edema in seminiferous tubules, probably demonstrating the evolution of infection by $\mathbf{T}$. gondii (Table 1, Figures 2 and 3).
The results obtained in this study regarding the clinical parameters are similar to those reported by KUHN et al. (1972) and DUBEY (1985).

\section{CONCLUSION}

The histopathological results in the present research, together with detection of Toxoplasma gondii in fragments of testicle and epididymis by immunohistochemistry and the results reported in the literature by other authors in different tissues all infer that the alterations observed in dogs infected with the protozoan are suggestive of toxoplasmic infection.

Table 1 - Histopathological findings in testicle and epididymis fragments of noninoculated (control) and dogs infected with $2.0 \mathrm{x} 10^{5}$ oocysts or $1.0 \times 10^{6}$ tachyzoites of Toxoplasma gondii.

\begin{tabular}{|c|c|c|c|c|c|c|c|c|c|c|}
\hline \multirow{3}{*}{ Lesions observed } & \multicolumn{10}{|c|}{--------------Inoculate/Dog identificationsem negrito--------------- } \\
\hline & \multicolumn{3}{|c|}{------Oocysts------ } & \multicolumn{3}{|c|}{----Tachyzoites---- } & \multicolumn{4}{|c|}{-----Control------ } \\
\hline & 14 & 31 & 71 & 1 & 15 & 24 & 5 & 21 & 22 & 75 \\
\hline Mild interstitial mononuclear inflammatory infiltrate & + & + & + & + & - & + & - & - & - & - \\
\hline Moderate interstitial mononuclear inflammatory infiltrate & + & + & - & + & + & + & - & - & - & - \\
\hline Moderate cellular edema of the seminiferous tubules & - & + & + & - & + & - & - & - & - & - \\
\hline Inflammatory infiltrate chronic of the $\&$ moderate interstitial fibrosis & - & - & - & + & - & - & - & - & - & - \\
\hline
\end{tabular}

+ : Positive.

-: Negative. 


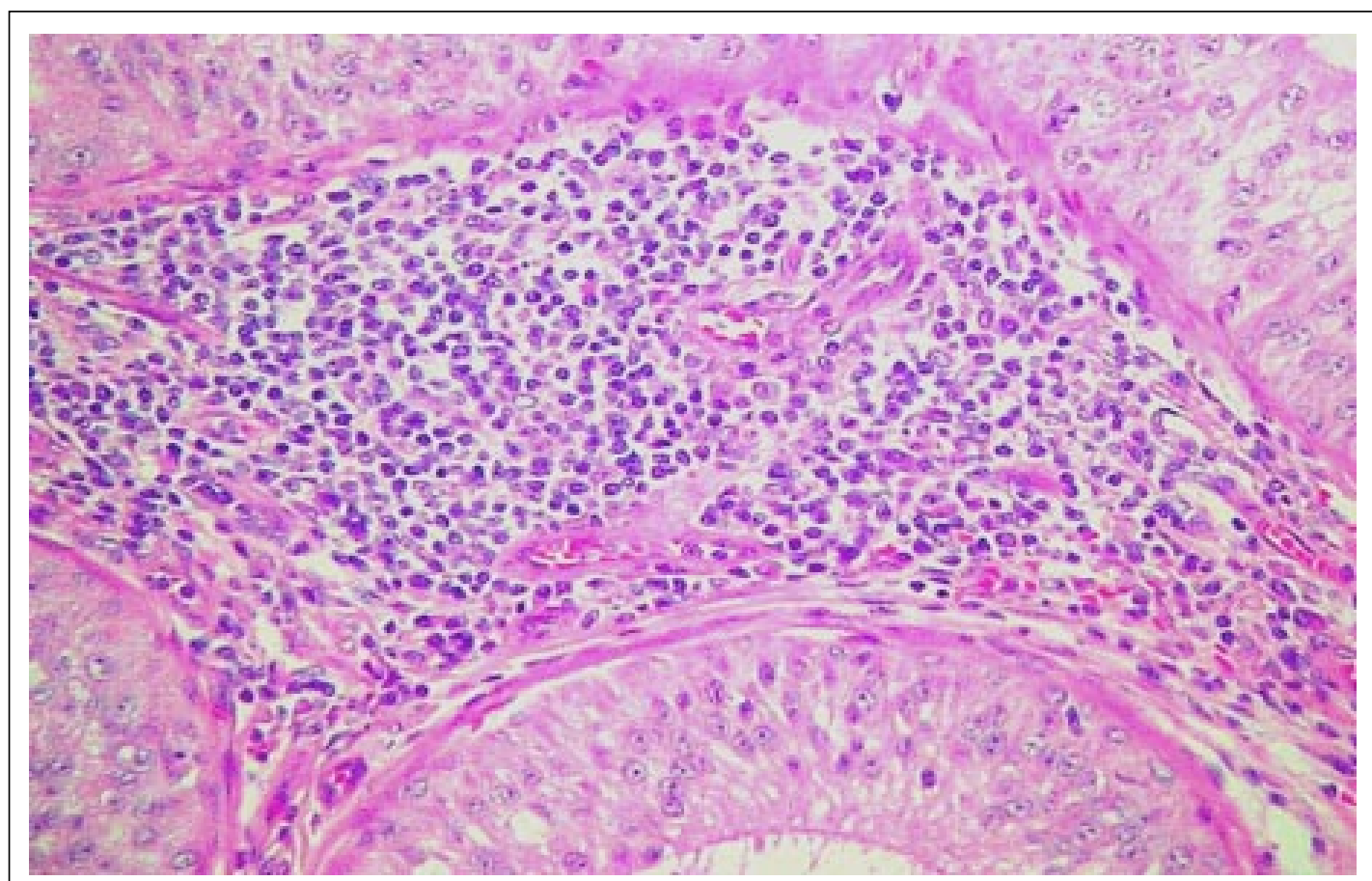

Figure 2 - Epididymis photomicrography of dog inoculated with oocysts of Toxoplasma gondii, demonstrating multifocal interstitial mononuclear inflammatory infiltrate. Objectivelens 10x, HE staining.

\section{ETHICAL COMMITTEE AND BIOSECURITY}

In this study, all procedures using animals complied with the Ethical Principles in Animal Research adopted by the
College of Animal Experimentation (COBEA - protocol number 013497-08) and were approved by the Ethical Committee for Animal Welfare, UNESP, Jaboticabal, São Paulo, Brazil (CEBEA).

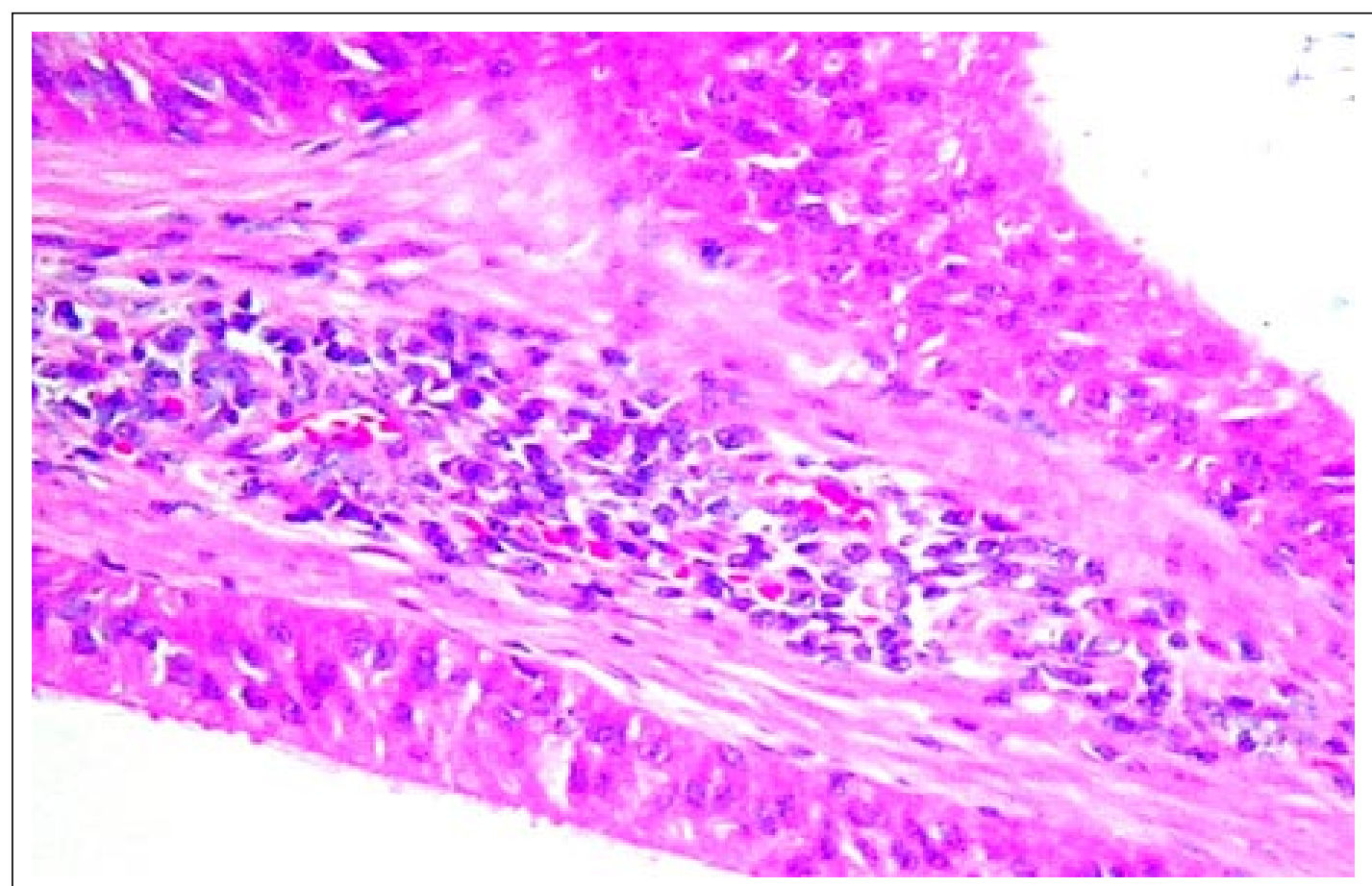

Figure 3 - Epididymis photomicrography of dog inoculated with tachyzoites of Toxoplasma gondii, demonstrating inflammatory infiltrate chronic and moderate interstitial fibrosis. Objective lens 10x, HE staining.

Ciência Rural, v.39, n.7, out, 2009. 


\section{REFERENCES}

ARANTES, T.P. Transmissão sexual do Toxoplasma gondii em cães (Canis familiares). 2005. 83f. Dissertação (Mestrado em Patologia Animal) - Jaboticabal, FCAV - Universidade Estadual Paulista.

BRESCIANI, K.D.S. Estudo da inoculação de oocistos e taquizoítos de Toxoplasma gondii em cadelas gestantes naturalmente infectadas. 2003. 120f. Tese (Doutorado em Medicina Veterinária Preventiva) - FCAV - Universidade Estadual Paulista, Jaboticabal, SP.

BRITO, A.F. et al. Epidemiological and serological aspects in canine Toxoplasmosis in Animals with nervous symptoms. Memórias do Instituto Oswaldo Cruz, v.97, p.1-5, 2002. Disponível em: $<$ http://www.scielo.br/scielo.php?script=sci_issuetoc\&pid=0074$027620020001 \& \operatorname{lng}=\mathrm{pt} \& \mathrm{nrm}=\mathrm{iso}>$. Acesso em: 15/06/2009. doi: $10.1590 / \mathrm{S} 0074-02762002000100003$.

CAMARGO, M.E. Improvided technique of indirect immunofluorescence for serological diagnosis of toxoplasmosis. Revista do Instituto de Medicina Tropical, v.06, p.117$118,1964$.

DUBEY, J.P.et al. Simplified method for isolation of .gondii from the feces of cats. Journal of Parasitology, v.58, p.10551056,1972 .

DUBEY, J.P. Toxoplasmosis in dogs. Canine Practice, v.28, p.7-28, 1985

DUBEY, J.P. et al. Sources and reservoirs of Toxoplasma gondii infection on 47 swine farms in Illions. Journal of Parasitology, v.81, p.723-729, 1995.
FIALHO, S.A. Toxoplasmose ocular. Contribuição ao estudo clínico e experimental. 1953. 139f. Tese (Doutorado em Medicina) - Faculdade Nacional de Medicina do Brasil, Rio de Janeiro.

GUESDON, J.L. et al. The use of avidin-biotin interaction in immunoenzymatic techniques. Journal Histochemistry and Cytochemistry, v.27, p.1131-1139, 1979.

HEDLEY, D.M. Toxoplasmosis. Journal of Small Animal Practice, v.4, p.435-446, 1963.

JAMARA, L.M.F.; VIEIRA, M.P.L. Isolamento do Toxopalsma gondii de exudato peritoneal e órgãos de camundongos com infecção experimental. Revista do Instituto de Medicina Tropical, v.33, p.435-441, 1991

KUHN, D. et al. Experimentelle infektion von Hunden mit Toxoplasma - Oozysten. Berliner und Munchener Tierarztliche Wochenschrift, v.85, p.309, 1972.

MELLO, V. Un cas de toxoplasmose du chien observé à Turin Bulletin of the Exotic Pathology Society, v.28, p.359-363, 1910 .

NICOLLE, C.; MANCEAUX, L. Sur un protozoaire nouveau du gondii. C.R. Academic Science, v.148, p.369, 1909.

SABIN, A.B. Toxoplasmic encephalitis in children. Journal of the American Medicine Association, v.116, p.801-807, 1941 .

SILVA, N.M. et al. Optimisation of cut-off titre in Toxoplasma gondii specific Elisa AND IFAT in dog sera using immunoreactivity to G-1 antigens as a molecular marker of infection. Veterinary Journal, v.163, p.94-98, 2002. doi:10.1053/tvj1.2001.0629. 